\title{
Preoperative systemic immune-inflammation index predicts prognosis of patients with non-metastatic renal cancer carcinoma: a propensity score- matched analysis
}

\section{Xu Hu}

Sichuan University West China Hospital

\section{Yan-Xiang Shao}

Sichuan University West China Hospital

Zhi-Qiang Yang

Sichuan University West China Hospital

Wei-Chao Dou

Sichuan University West China Hospital

\section{San-Chao Xiong}

Sichuan University West China Hospital

Xiang Li ( $\square$ hx_uro@sina.com )

Sichuan University West China Hospital https://orcid.org/0000-0003-0765-1546

\section{Primary research}

Keywords: systemic immune-inflammation index; renal cell carcinoma; non-metastatic; prognosis

Posted Date: April 7th, 2020

DOI: https://doi.org/10.21203/rs.3.rs-20916/v1

License: (c) (1) This work is licensed under a Creative Commons Attribution 4.0 International License.

Read Full License

Version of Record: A version of this preprint was published at Cancer Cell International on June 8th, 2020. See the published version at https://doi.org/10.1186/s12935-020-01320-w. 


\section{Abstract}

Background: A novel systemic immune-inflammation index (SII), based on the neutrophils, lymphocytes and platelet counts, is associated with the prognosis of several cancers. The present study evaluates the prognostic significance of SII in non-metastatic renal cell carcinoma (RCC).

Method: The present study retrospectively reviewed the medical record of patients with non-metastatic RCC who underwent nephrectomy between 2010 and 2013. Receiver operating characteristic (ROC) curve analysis was performed to identify the optimal cut-off value. In addition, the propensity score matching (PSM) was performed with a matching ratio of 1:1. Univariate and multivariate Cox proportional hazards models were used to identify the prognostic factors. The results were reported by hazard ratio (HR) with $95 \%$ confidence interval $(95 \% \mathrm{Cl})$.

Results: A total of 646 patients were included in the final analysis. High SII group (>529) was significantly associated with older age $(P=0.014)$, larger tumor $(P<0.001)$, higher pathological T stage $(P<0.001)$, higher tumor grade $(P<0.001)$ and more tumor necrosis $(P<0.001)$. Multivariate Cox regression analysis demonstrated that the higher preoperative SII was significantly associated with worse OS (HR=2.26; $95 \% \mathrm{Cl} 1.44-3.54 ; \mathrm{P}<0.001)$ and CSS $(\mathrm{HR}=2.17 ; 95 \% \mathrm{Cl} 1.33-3.55 ; \mathrm{P}=0.002)$. After PSM, elevated preoperative SII was an independent predictor of poor OS (HR=1.78; 95\% $\mathrm{Cl} 1.1-2.87 ; \mathrm{P}=0.018)$ and CSS $(\mathrm{HR}=1.8 ; 95 \% \mathrm{Cl} 1.07-3.03 ; \mathrm{P}=0.027)$.

Conclusion: In conclusion, preoperative SII is associated with adverse factors for RCC. Furthermore, higher preoperative SII is an independent predictor of poor OS and CSS in surgically treated patients with non-metastatic RCC. While more prospective and large scale studies are warranted to validate our findings.

\section{Background}

Renal cell carcinoma (RCC) is one of the most common urological cancers, represents an increased global burden on human healthcare ${ }^{1}$. RCC accounts for approximately $2 \%-3 \%$ of all malignancies, with an estimated 403,262 new cases and 175,098 new deaths worldwide in $2018^{2}$. Surgical resection is the curative treatment for localized RCC ${ }^{3}$. However, reportedly, about $20-30 \%$ of patients will develop recurrence $e^{4-5}$. Nowadays, several treatment strategies have developed well, such as immunotherapy, radiotherapy and molecular target drugs, and the clinical outcomes of the advanced disease have been improved ${ }^{3,6-7}$. However, the clinical outcomes remain not encouraging due to the low objective response rate, local recurrence of distant metastases. Therefore, identifying the prognostic factors of patients would be of great value to patients' risk stratification, treatment selection, and long-term outcomes.

TNM stage, tumor grade, and histology are commonly used prognostic factors, however, these factors would miss information associated patient-related factors. Increasing evidence suggested that host inflammation response plays an important role in cancer development and progression ${ }^{8-9}$. Previous 
reported have reported that immune-inflammatory circulating cells, such as lymphocytes, neutrophils, and platelet, could contribute to promoting cancer cell proliferation and invasion ${ }^{8-11}$. Several studies have evaluated these circulating cells and found that these are associated with the prognosis of malignancies ${ }^{11-12}$.

A novel systemic immune-inflammation index (SII), based on the neutrophils, lymphocytes and platelet counts, has been found to be associated with the prognosis of several cancers, such as gastric cancer, hepatocellular carcinoma, bladder cancer as well as $\mathrm{RCC}^{13-16}$. However, the prognostic value of SII in non-metastatic RCC is not well explored. Hence, the present study was performed to evaluate the prognostic significance of preoperative SII in non-metastatic RCC who underwent nephrectomy.

\section{Material And Methods}

\section{Patients}

After approval by the institutional review board of Sichuan University West China Hospital, the present study retrospectively reviewed the medical record of patients with non-metastatic RCC who underwent nephrectomy between 2010 and 2013. Patients with multiple tumors, presence of inflammation, insufficient information, positive lymph node, and distant metastasis were excluded. At last, a total of 646 patients were included in the final analysis.

The following clinicopathological characteristics were retracted from medical records: age, gender, hypertension, diabetes mellitus, tumor laterality, surgical approach and type, tumor stage, grade, neutrophils, lymphocytes, and platelet counts. All laboratory tests were performed within 1 week before surgery. SIl was calculated based on the following formula: platelet $\times$ neutrophil/lymphocyte. In addition, the X-ray or computed tomography (CT) scan of the chest and CT or magnetic resonance imaging (MRI) scan of the abdomen should be performed for patients to identify the preoperative stage. Lymph node dissection was conducted in patients with enlarged nodes on preoperative imaging or palpable nodes during surgery. The pathological stage was classified based on the 8th edition of the tumor-nodemetastasis (TNM) classification ${ }^{17}$. The pathological evaluation was made according to the 2016 WHO classification $^{18}$.

\section{Follow-up Data}

All patients were followed up regularly, every 3 months within 2 years after surgery, every 6 months for the next 3 years, and then once a year. Patients should undergo a medical history, physical examination, laboratory test, X-ray or CT of the chest, ultrasound or CT or MRI of the abdomen. The clinical outcomes include overall survival (OS) and cancer-specific survival (CSS). OS is defined as the interval time between the day of surgery and the last follow-up or all-cause death. CSS is measured from the day of surgery and last follow-up or cancer-related death. 


\section{Statistical analysis}

Continuous variables are presented as mean \pm standard derivation (SD) or median (interquartile range, IQR). Categorized variables are described as frequency (percentage). Chi-square test and Student' $t$ test were used to compare the categorized and continuous variables, respectively. Receiver operating characteristic (ROC) curve analysis was performed to identify the sensitivity and specificity of the prognostic factor. The optimal cut-off value of the prognostic factor was chosen based on the Youden Index. Kaplan-Meier survival curve and the log-rank test were carried out to compare the survival outcomes between groups. Univariate and multivariate Cox proportional hazards models were used to identify the prognostic factors of OS and CSS. The results were reported by hazard ratio (HR) with $95 \%$ confidence interval $(95 \% \mathrm{Cl})$.

In addition, the propensity score matching (PSM) was performed using the nearest neighbor method with 0.02 calibration adjusting for preoperative characteristics. The matching ratio is 1:1, and SII (low vs high) is the dependent variable. The standardized difference was calculated to evaluate the covariate balance, with a value $<0.10$ regarded as balanced ${ }^{19}$. A two-tailed P-value $<0.05$ was regarded as statistically significant. All statistical analyses were performed by R software version 3.6.2 (http://www.r-project.org/) and IBM SPSS Statistics version 23.0 (IBM Corp, Armonk, NY).

\section{Results}

\section{Clinical characteristics of patients}

The clinical characteristics of the included patients were summarized in Table 1. The mean age of the patients was 54.77 years (SD \pm 12.61$)$. The final cohort included 394 men $(60.99 \%)$ and 252 women (39.01\%) with a mean tumor size of $4.97 \mathrm{~cm}(S D \pm 2.53)$. More than half of the patients received open surgery $(69.81 \%)$ and radical nephrectomy $(67.49 \%)$. Most patients $(n=543,84.06 \%)$ had clear cell RCC. Pathological T stage was T1 in 522 cases (80.80\%), T2 in 53 (8.2\%), T3 in 63 (9.75\%), and T4 in 8 (1.24\%). The median follow-up was 84 months (IQR, 75-93 months). 
Table 1

Clinical characteristics of the patients

\begin{tabular}{|c|c|c|c|c|c|c|c|}
\hline & & Before PS & & & After PSM & & \\
\hline & Total & SII & & & SII & & \\
\hline & & $<529$ & $>529$ & $\begin{array}{l}\mathrm{P}- \\
\text { value }\end{array}$ & $<529$ & $>529$ & $\begin{array}{l}\mathrm{P} \text { - } \\
\text { value }\end{array}$ \\
\hline No. of patients & 646 & 483 & 163 & & 163 & 163 & \\
\hline Age (years) & $\begin{array}{l}54.77 \pm \\
12.61\end{array}$ & $\begin{array}{l}54.03 \pm \\
12.52\end{array}$ & $\begin{array}{l}56.95 \pm \\
12.68\end{array}$ & 0.014 & $\begin{array}{l}54.93 \pm \\
12.84\end{array}$ & $\begin{array}{l}56.95 \pm \\
12.68\end{array}$ & 0.214 \\
\hline $\begin{array}{l}\text { Gender } \\
\text { Male } \\
\text { Female }\end{array}$ & $\begin{array}{l}394 \\
(60.99 \%) \\
252 \\
(39.01 \%)\end{array}$ & $\begin{array}{l}287 \\
(59.42 \%) \\
196 \\
(40.58 \%)\end{array}$ & $\begin{array}{l}107 \\
(65.64 \%) \\
56 \\
(34.36 \%)\end{array}$ & 0.159 & $\begin{array}{l}105 \\
(64.42 \%) \\
58 \\
(35.58 \%)\end{array}$ & $\begin{array}{l}107 \\
(65.64 \%) \\
56 \\
(34.36 \%)\end{array}$ & 0.816 \\
\hline Hypertension & $\begin{array}{l}169 \\
(26.16 \%)\end{array}$ & $\begin{array}{l}114 \\
(23.60 \%)\end{array}$ & $\begin{array}{l}55 \\
(33.74 \%)\end{array}$ & 0.011 & $\begin{array}{l}44 \\
(26.99 \%)\end{array}$ & $\begin{array}{l}55 \\
(33.74 \%)\end{array}$ & 0.185 \\
\hline Diabetes mellitus & $\begin{array}{l}77 \\
(11.92 \%)\end{array}$ & $\begin{array}{l}51 \\
(10.56 \%)\end{array}$ & $\begin{array}{l}26 \\
(15.95 \%)\end{array}$ & 0.066 & $\begin{array}{l}18 \\
(11.04 \%)\end{array}$ & $\begin{array}{l}26 \\
(15.95 \%)\end{array}$ & 0.195 \\
\hline $\begin{array}{l}\text { Laterality } \\
\text { Left } \\
\text { Right }\end{array}$ & $\begin{array}{l}313 \\
(48.45 \%) \\
333 \\
(51.55 \%)\end{array}$ & $\begin{array}{l}227 \\
(47.00 \%) \\
256 \\
(53.00 \%)\end{array}$ & $\begin{array}{l}86 \\
(52.76 \%) \\
77 \\
(47.24 \%)\end{array}$ & 0.203 & $\begin{array}{l}80 \\
(49.08 \%) \\
83 \\
(50.92 \%)\end{array}$ & $\begin{array}{l}86 \\
(52.76 \%) \\
77 \\
(47.24 \%)\end{array}$ & 0.506 \\
\hline Tumor size $(\mathrm{cm})$ & $\begin{array}{l}4.97 \pm \\
2.53\end{array}$ & $\begin{array}{l}4.57 \pm \\
2.13\end{array}$ & $\begin{array}{l}6.16 \pm \\
3.16\end{array}$ & $\hat{0}_{0.001}$ & $\begin{array}{l}5.85 \pm \\
2.71\end{array}$ & $\begin{array}{l}6.16 \pm \\
3.16\end{array}$ & 0.641 \\
\hline $\begin{array}{l}\text { Operative approach } \\
\text { Open } \\
\text { Laparoscopic }\end{array}$ & $\begin{array}{l}451 \\
(69.81 \%) \\
195 \\
(30.19 \%)\end{array}$ & $\begin{array}{l}332 \\
(68.74 \%) \\
151 \\
(31.26 \%)\end{array}$ & $\begin{array}{l}119 \\
(73.01 \%) \\
44 \\
(26.99 \%)\end{array}$ & 0.305 & $\begin{array}{l}122 \\
(74.85 \%) \\
41 \\
(25.15 \%)\end{array}$ & $\begin{array}{l}119 \\
(73.01 \%) \\
44 \\
(26.99 \%)\end{array}$ & 0.705 \\
\hline $\begin{array}{l}\text { Nephrectomy } \\
\text { Radical } \\
\text { Partial }\end{array}$ & $\begin{array}{l}436 \\
(67.49 \%) \\
210 \\
(32.51 \%)\end{array}$ & $\begin{array}{l}308 \\
(63.77 \%) \\
175 \\
(36.23 \%)\end{array}$ & $\begin{array}{l}128 \\
(78.53 \%) \\
35 \\
(21.47 \%)\end{array}$ & $\begin{array}{l}<.001 \\
0 .\end{array}$ & $\begin{array}{l}124 \\
(76.07 \%) \\
39 \\
(23.93 \%)\end{array}$ & $\begin{array}{l}128 \\
(78.53 \%) \\
35 \\
(21.47 \%)\end{array}$ & 0.597 \\
\hline $\begin{array}{l}\text { Pathological T } \\
\text { stage } \\
\text { T1 } \\
\text { T2 } \\
\text { T3 } \\
\text { T4 }\end{array}$ & $\begin{array}{l}522 \\
(80.80 \%) \\
53 \\
(8.20 \%) \\
63 \\
(9.75 \%) \\
8 \\
(1.24 \%)\end{array}$ & $\begin{array}{l}413 \\
(85.51 \%) \\
32 \\
(6.63 \%) \\
34 \\
(7.04 \%) \\
4 \\
(0.83 \%)\end{array}$ & $\begin{array}{l}109 \\
(66.87 \%) \\
21 \\
(12.88 \%) \\
29 \\
(17.79 \%) \\
4 \\
(2.45 \%)\end{array}$ & $<.001$ & $\begin{array}{l}111 \\
(68.10 \%) \\
28 \\
(17.18 \%) \\
21 \\
(12.88 \%) \\
3 \\
(1.84 \%)\end{array}$ & $\begin{array}{l}109 \\
(66.87 \%) \\
21 \\
(12.88 \%) \\
29 \\
(17.79 \%) \\
4 \\
(2.45 \%)\end{array}$ & 0.486 \\
\hline $\begin{array}{l}\text { Histologic subtype } \\
\text { Clear cell } \\
\text { Non-clear cell }\end{array}$ & $\begin{array}{l}543 \\
(84.06 \%) \\
103 \\
(15.94 \%)\end{array}$ & $\begin{array}{l}405 \\
(83.85 \%) \\
78 \\
(16.15 \%)\end{array}$ & $\begin{array}{l}138 \\
(84.66 \%) \\
25 \\
(15.34 \%)\end{array}$ & 0.807 & $\begin{array}{l}141 \\
(86.50 \%) \\
22 \\
(13.50 \%)\end{array}$ & $\begin{array}{l}138 \\
(84.66 \%) \\
25 \\
(15.34 \%)\end{array}$ & 0.636 \\
\hline
\end{tabular}




\begin{tabular}{|llllllll|}
\hline & \multicolumn{5}{c}{ Before PSM } & \multicolumn{5}{c|}{ After PSM } \\
\hline Tumor grade & 24 & 20 & 4 & $<$ & 3 & 4 & 0.145 \\
G1 & $(3.72 \%)$ & $(4.14 \%)$ & $(2.45 \%)$ & 0.001 & $(1.84 \%)$ & $(2.45 \%)$ & \\
G2 & 340 & 276 & 64 & & 72 & 64 & \\
G3 & $(52.63 \%)$ & $(57.14 \%)$ & $(39.26 \%)$ & & $(44.17 \%)$ & $(39.26 \%)$ & \\
G4 & 263 & 181 & 82 & & 84 & 82 & \\
& $(40.71 \%)$ & $(37.47 \%)$ & $(50.31 \%)$ & & $(51.53 \%)$ & $(50.31 \%)$ & \\
& 19 & 6 & 13 & & 4 & 13 & \\
& $(2.94 \%)$ & $(1.24 \%)$ & $(7.98 \%)$ & & $(2.45 \%)$ & $(7.98 \%)$ & \\
\hline Tumor necrosis & 71 & 38 & 33 & $<$ & 32 & 33 & 0.890 \\
& $(10.99 \%)$ & $(7.87 \%)$ & $(20.25 \%)$ & 0.001 & $(19.63 \%)$ & $(20.25 \%)$ & \\
\hline Sarcomatoid & 7 & 3 & 4 & 0.072 & 2 & 4 & 0.685 \\
differentiations & $(1.08 \%)$ & $(0.62 \%)$ & $(2.45 \%)$ & & $(1.23 \%)$ & $(2.45 \%)$ & \\
\hline
\end{tabular}

The optimal cut-off value of SII is 529 based on the maximum Youden index (Fig. 1). Thus, the patients were divided into two groups. The patients in high SII group (> 529) was significantly associated with older age $(P=0.014)$, larger tumor $(P<0.001)$, higher pathological T stage $(P<0.001)$, higher tumor grade $(P<0.001)$ and more tumor necrosis $(P<0.001)$, compared with those in low Sll group $(<529)$. After PSM, 163 paired patients were identified, and there was no significant difference in baseline between low and high SIl group.

\section{Association between preoperative SII and survival outcomes before PSM}

After a median follow-up of 84 months, 85 patients (13.16\%) had died and 71 deaths $(10.99 \%)$ were related to RCC. The 5-year OS rates were $93.79 \%$ and $76.67 \%$ for the patients in low SII and high SII groups, respectively. The 5-year CSS rate was $94.39 \%$ for the low SIl group, $79.38 \%$ for the high SIl group. Kaplan-Meier survival curve showed that the low SII had a better OS $(P<0.001$; Fig. $2 A)$ and CSS $(P<$ 0.001; Fig. 2B) than the high SIl group. Besides, the multivariate Cox regression analysis demonstrated that the higher preoperative SII was significantly associated with worse survival outcomes in terms of OS $(\mathrm{HR}=2.26 ; 95 \% \mathrm{Cl} 1.44-3.54 ; \mathrm{P}<0.001)$ and $\mathrm{CSS}(\mathrm{HR}=2.17 ; 95 \% \mathrm{Cl} 1.33-3.55 ; \mathrm{P}=0.002)$. Furthermore, age, surgical approach and type, $\mathrm{T}$ stage, tumor grade, tumor necrosis, and sarcomatoid feature were also the independent predictors of prognosis (Table 2). 
Table 2

Univariate and Multivariate Analyses of Prognostic Factors for OS, CSS and PFS in patients with nonmetastatic RCC $(n=646)$

\begin{tabular}{|c|c|c|c|c|}
\hline & OS & & css & \\
\hline & Univariate & Multivariate & Univariate & Multivariate \\
\hline & $\begin{array}{l}\mathrm{HR}(95 \% \mathrm{Cl}) \mathrm{P}- \\
\text { value }\end{array}$ & $\begin{array}{l}\mathrm{HR}(95 \% \mathrm{Cl}) \mathrm{P}- \\
\text { value }\end{array}$ & $\begin{array}{l}\mathrm{HR}(95 \% \mathrm{Cl}) \mathrm{P}- \\
\text { value }\end{array}$ & $\begin{array}{l}\mathrm{HR}(95 \% \mathrm{Cl}) \mathrm{P}- \\
\text { value }\end{array}$ \\
\hline Age $(\geqq 55$ vs $<55)$ & $\begin{array}{l}2.9(1.79-4.72) \\
<0.001\end{array}$ & $\begin{array}{l}1.77(1.07-2.92) \\
0.025\end{array}$ & $\begin{array}{l}2.39(1.44-3.98) \\
0.001\end{array}$ & \\
\hline $\begin{array}{l}\text { Gender (male vs } \\
\text { female) }\end{array}$ & $\begin{array}{l}1.19(0.76-1.86) \\
0.437\end{array}$ & & $\begin{array}{l}1.28(0.78-2.09) \\
0.332\end{array}$ & \\
\hline $\begin{array}{l}\text { Surgical approach } \\
\text { (laparoscopic vs } \\
\text { open) }\end{array}$ & $\begin{array}{l}0.29(0.15-0.56) \\
<0.001\end{array}$ & $\begin{array}{l}0.41(0.21-0.81) \\
0.009\end{array}$ & $\begin{array}{l}0.24(0.11-0.52) \\
<0.001\end{array}$ & $\begin{array}{l}0.36(0.16-0.79) \\
0.011\end{array}$ \\
\hline $\begin{array}{l}\text { Type of surgery } \\
\text { (partial vs radical) }\end{array}$ & $\begin{array}{l}0.17(0.08-0.37) \\
<0.001\end{array}$ & $\begin{array}{l}0.37(0.17-0.83) \\
0.016\end{array}$ & $\begin{array}{l}0.11(0.04-0.31) \\
<0.001\end{array}$ & $\begin{array}{l}0.29(0.1-0.82) \\
0.019\end{array}$ \\
\hline $\begin{array}{l}\text { Histology (non-clear } \\
\text { cell } \\
\text { vs clear cell) }\end{array}$ & $\begin{array}{l}0.96(0.53-1.74) \\
0.896\end{array}$ & & $\begin{array}{l}1.08(0.58-2.01) \\
0.807\end{array}$ & \\
\hline $\begin{array}{l}\text { T stage (3-4 vs } 1- \\
2 \text { ) }\end{array}$ & $\begin{array}{l}8.9(5.78-13.7) \\
<0.001\end{array}$ & $\begin{array}{l}3.99(2.5-6.37) \\
<0.001\end{array}$ & $\begin{array}{l}12.4(7.77-19.8) \\
<0.001\end{array}$ & $\begin{array}{l}5.25(3.16-8.7) \\
<0.001\end{array}$ \\
\hline $\begin{array}{l}\text { Tumor grade (G3-4 } \\
\text { vs G1-2) }\end{array}$ & $\begin{array}{l}4.4(2.69-7.21) \\
<0.001\end{array}$ & $\begin{array}{l}1.83(1.06-3.14) \\
0.03\end{array}$ & $\begin{array}{l}5.83(3.25-10.5) \\
<0.001\end{array}$ & $\begin{array}{l}2.15(1.14-4.08) \\
0.019\end{array}$ \\
\hline $\begin{array}{l}\text { Tumor necrosis (yes } \\
\text { vs no) }\end{array}$ & $\begin{array}{l}5.29(3.39-8.26) \\
<0.001\end{array}$ & $\begin{array}{l}2.38(1.49-3.79) \\
<0.001\end{array}$ & $\begin{array}{l}6.2(3.85-9.99) \\
<0.001\end{array}$ & $\begin{array}{l}2.65(1.62-4.36) \\
<0.001\end{array}$ \\
\hline $\begin{array}{l}\text { Sarcomatoid feature } \\
\text { (yes vs no) }\end{array}$ & $\begin{array}{l}10.66(4.3-26.4) \\
<0.001\end{array}$ & $\begin{array}{l}2.92(1.14-7.45) \\
0.025\end{array}$ & $\begin{array}{l}12.6(5.06-31.5) \\
<0.001\end{array}$ & $\begin{array}{l}3.72(1.44-9.6) \\
0.007\end{array}$ \\
\hline SII $(>529$ vs < 529) & $\begin{array}{l}4.23(2.76-6.49) \\
<0.001\end{array}$ & $\begin{array}{l}2.26(1.44-3.54) \\
<0.001\end{array}$ & $\begin{array}{l}4.38(2.74-7.01) \\
<0.001\end{array}$ & $\begin{array}{l}2.17(1.33-3.55) \\
0.002\end{array}$ \\
\hline
\end{tabular}

\section{Association between preoperative SII and survival outcomes after PSM}

After a median follow-up of 81 months, 74 patients (22.70\%) had died and 63 deaths (19.33\%) were related to RCC. The 5-year OS rates were $86.50 \%$ and $76.67 \%$ for the patients in low SII and high SII groups, respectively. The 5-year CSS rate was $88.24 \%$ for the low SII group, $79.38 \%$ for the high SII group. Kaplan-Meier survival curve indicated that higher preoperative SII was associated with inferior OS $(\mathrm{P}=$ 0.006; Fig. 3A) and CSS ( $=0.012$; Fig. 3B). Based on the multivariate analysis, the elevated preoperative SIl was an independent predictor of poor prognosis regarding $\mathrm{OS}(\mathrm{HR}=1.78 ; 95 \% \mathrm{Cl} 1.1-2.87 ; \mathrm{P}=0.018)$ and CSS $(\mathrm{HR}=1.8 ; 95 \% \mathrm{Cl} 1.07-3.03 ; \mathrm{P}=0.027$; Table 3$)$. 
Table 3

Univariate and Multivariate Analyses of Prognostic Factors for OS, CSS and PFS in patients with nonmetastatic RCC after PSM $(n=326)$

\begin{tabular}{|c|c|c|c|c|}
\hline & OS & & css & \\
\hline & Univariate & Multivariate & Univariate & Multivariate \\
\hline & $\begin{array}{l}\mathrm{HR}(95 \% \mathrm{Cl}) \mathrm{P}- \\
\text { value }\end{array}$ & $\begin{array}{l}\mathrm{HR}(95 \% \mathrm{Cl}) \mathrm{P}- \\
\text { value }\end{array}$ & $\begin{array}{l}\mathrm{HR}(95 \% \mathrm{Cl}) \mathrm{P}- \\
\text { value }\end{array}$ & $\begin{array}{l}\mathrm{HR}(95 \% \mathrm{Cl}) \mathrm{P}- \\
\text { value }\end{array}$ \\
\hline Age $(\geqq 55$ vs $<55)$ & $\begin{array}{l}2.06(1.25-3.4) \\
0.004\end{array}$ & & $\begin{array}{l}1.74(1.03-2.94) \\
0.038\end{array}$ & \\
\hline $\begin{array}{l}\text { Gender (male vs } \\
\text { female) }\end{array}$ & $\begin{array}{l}1.16(0.71-1.89) \\
0.550\end{array}$ & & $\begin{array}{l}1.39(0.81-2.41) \\
0.234\end{array}$ & \\
\hline $\begin{array}{l}\text { Surgical approach } \\
\text { (laparoscopic vs } \\
\text { open) }\end{array}$ & $\begin{array}{l}0.31(0.15-0.65) \\
0.002\end{array}$ & $\begin{array}{l}0.42(0.2-0.87) \\
0.021\end{array}$ & $\begin{array}{l}0.22(0.09-0.55) \\
0.001\end{array}$ & $\begin{array}{l}0.32(0.13-0.8) \\
0.015\end{array}$ \\
\hline $\begin{array}{l}\text { Type of surgery } \\
\text { (partial vs radical) }\end{array}$ & $\begin{array}{l}0.17(0.06-0.46) \\
0.001\end{array}$ & $\begin{array}{l}0.31(0.11-0.88) \\
0.028\end{array}$ & $\begin{array}{l}0.15(0.05-0.47) \\
0.001\end{array}$ & \\
\hline $\begin{array}{l}\text { Histology (non-clear } \\
\text { cell } \\
\text { vs clear cell) }\end{array}$ & $\begin{array}{l}0.71(0.34-1.48) \\
0.365\end{array}$ & & $\begin{array}{l}0.86(0.41-1.8) \\
0.682\end{array}$ & \\
\hline $\begin{array}{l}T \text { stage (3-4 vs } 1- \\
2)\end{array}$ & $\begin{array}{l}\begin{array}{l}6.4(4.04-10.14) \\
<0.001\end{array}\end{array}$ & $\begin{array}{l}4.09(2.49-6.71) \\
<0.001\end{array}$ & $\begin{array}{l}8.91(5.4-14.7) \\
<0.001\end{array}$ & $\begin{array}{l}5.39(3.14-9.25) \\
<0.001\end{array}$ \\
\hline $\begin{array}{l}\text { Tumor grade (G3-4 } \\
\text { vs G1-2) }\end{array}$ & $\begin{array}{l}2.79(1.64-4.75) \\
<0.001\end{array}$ & & $\begin{array}{l}3.81(2.03-7.14) \\
<0.001\end{array}$ & \\
\hline $\begin{array}{l}\text { Tumor necrosis (yes } \\
\text { vs no) }\end{array}$ & $\begin{array}{l}2.91(1.83-4.65) \\
<0.001\end{array}$ & $\begin{array}{l}2.15(1.33-3.48) \\
0.002\end{array}$ & $\begin{array}{l}3.38(2.05-5.57) \\
<0.001\end{array}$ & $\begin{array}{l}2.45(1.46-4.09) \\
0.001\end{array}$ \\
\hline $\begin{array}{l}\text { Sarcomatoid feature } \\
\text { (yes vs no) }\end{array}$ & $\begin{array}{l}5.53(2.01-15.2) \\
<0.001\end{array}$ & & $\begin{array}{l}6.55(2.37-18.1) \\
<0.001\end{array}$ & $\begin{array}{l}3.27(1.14-9.37) \\
0.028\end{array}$ \\
\hline SII $(>529$ vs $<529)$ & $\begin{array}{l}1.92(1.19-3.08) \\
0.007\end{array}$ & $\begin{array}{l}1.78(1.1-2.87) \\
0.018\end{array}$ & $\begin{array}{l}1.91(1.14-3.19) \\
0.013\end{array}$ & $\begin{array}{l}1.8(1.07-3.03) \\
0.027\end{array}$ \\
\hline
\end{tabular}

\section{Discussion}

In the present study, we explored the prognostic value of preoperative SII in non-metastatic RCC patients who underwent nephrectomy. We observed that high SII is likely to be associated with adverse factors, such as age, tumor size, pathological T stage, tumor grade, and necrosis. Multivariate analyses showed SIl was an independent predictor of OS and CSS. Moreover, to limit the influence of bias, we performed PSM and demonstrated that high SII was also an unfavorable factor for OS and CSS in the matched cohort. 
The association between inflammation and malignancy has been widely explored in the past decades. Immune cells play an essential role in the inflammatory process leading to the production of cytokines and chemokines that promote tumor development, invasion and metastasis ${ }^{8}$. Therefore, the complex balance between immune cells and substances secreted by inflammation may affect the type of cells detectable in the peripheral circulation. SII, a novel inflammation index, based on the neutrophil, platelet, and lymphocyte, was found to be associated with the prognosis of several malignancies. A retrospective multicenter cohort study revealed that high SII $(>900)$ is associated with poor CSS $(\mathrm{HR}=2.32 ; 95 \% \mathrm{Cl}$ $1.55-3.48$ ) in patients with resectable pancreatic cancer ${ }^{20}$. Chen et al included 1383 colorectal cancer patients and found high SII (>340) was an independent predictor of OS and disease-free survival ${ }^{21}$. Zhang et al. conducted a retrospective analysis of 209 patients with BC undergoing radical cystectomy, finding SII was an independent predictor for OS and provide more accurate prognostic predication than neutrophil-to-lymphocyte ratio (NLR), platelet-to-lymphocyte ratio (PLR), and C-reactive protein/albumin ratio $^{15}$. Similarly, Jan et al. observed that SII is superior to NLR, PLR and monocyte-to-lymphocyte ratio (MLR) as a predictor of survival in patients with UTUC ${ }^{22}$. Besides, a high SIl was associated with adverse characteristics such as lymphovascular invasion, positive lymph node, more aggressive phenotype, which is consistent with our findings.

Similarly, SIl was also reported to be associated with survival outcomes in patients with RCC. Chrom et al. involved $\mathrm{mRCC}$ patients treated with the tyrosine kinase inhibitor and found that high SII was an independent factor for inferior $\mathrm{OS}^{23}$. Besides, they found that the addition of the SII to the International Metastatic Renal Cell Carcinoma Consortium (IMDC) model in place of neutrophil and platelet counts increased the model's prognostic performance. Lolli et al. also included patients with mRCC treated with sunitinib and observed SII was associated with the $0 S^{16}$. To be noted, the improvement of SII value at 6 weeks (from $\geq 730$ to $<730$ ) was correlated to a better prognosis, as a possible effect of sunitinib on peripheral blood cells secondary to decline in inflammation process ${ }^{16}$. De Giorgi et al. suggested that SII appears superior to the NLR as a prognostic marker in $\mathrm{MRCC}$ patients treated with immune check-point inhibitors ${ }^{24}$. Furthermore, recently, a retrospective study of 176 RCC patients who underwent radical nephrectomy observed that high SII was associated with poor OS $(P=0.034)^{25}$. SII is also associated with an increased TNM stage, which is similar to our results. However, no significant association was found for $\operatorname{CSS}(P=0.29)$. Although their study was limited by the small number of patients and the short duration of follow-up, it was valuable for exploring the prognostic value of SII in the non-metastatic RCC. To the best of our knowledge, there are no other studies focusing on the prognostic impact of SII in surgically treated non-metastatic RCC patients. There is no standard cut-off value of SII, and the cut-off value of SII differs from study to study. Hence, the multicenter study is required to identify standard cutoff value.

The potential mechanism for the prognostic significance of this combination might be explained by the functions of neutrophil, platelet, and lymphocyte. Neutrophils promote angiogenesis and inhibit antitumor immune system response, leading to tumor development ${ }^{9-10,26}$. Neutrophils also play an important role in the lymphangiogenesis ${ }^{27}$. Furthermore, neutrophils could secret circulating growth 
factors such as vascular endothelial growth factor, facilitating adhesion and tumor seeding ${ }^{27-28}$. Huang et al. Observed that neutrophilia is an independent predictor of recurrence in patients with $\mathrm{RCC}^{29}$. Besides, the intratumoral neutrophil is associated with poor prognosis in patients with localized and metastatic $\mathrm{RCC}^{30-31}$. Platelet could protect circulating tumor cells (CTCs) during circulation, induce CTC epithelialmesenchymal transition, and facilitate the extraction of tumor cells, leading to the metastasis of tumor cells $^{32}$. Moschini et al. revealed that the platelet count was associated with survival in patients with $\mathrm{BC}^{33}$. Yun et al. also found that decreased mean platelet volume was independently associated with $\mathrm{RCC}^{34}$. Lymphocyte plays an important role in anti-tumor immunity. Lymphocyte could induce cytotoxic cell death and inhibit tumor proliferation and migration by secreting cytokines, leading to a host immune response to malignancy ${ }^{8}$. A decreased lymphocyte count might result in the attenuation of immunological anti-tumor response. Lymphopenia was found to be associated with inferior survival in patients with advanced bladder cancer and $\mathrm{RCC}^{35-36}$. Besides, higher tumor-infiltrating lymphocytes mean more strongly anti-tumor effect and better survival outcomes ${ }^{37}$. Therefore, the high SII, which reflects thrombocythemia, neutrophilia, or lymphopenia, suggesting weak adaptive immune response in patients. All of these could lead to more tumor cells escape from the host immune system, increasing circulating growth factors and tumor cells, and finally facilitating the tumor invasion and metastasis. Based on the above-mentioned evidence, high SIl could be served as an unfavorable factor in cancer patients. However, more large scale studies are required to verify our findings.

SII had significance in clinical practice. SII was calculated based on the neutrophil, platelet, and lymphocyte, which is convenient, easily obtained and commonly tested before the treatment. SII could predict the prognosis of patients, which could be used for risk stratification. It could provide physicians with useful information and guide the treatment, adjuvant therapy and follow-up for patients. But the individual conditions should be considered during the treatment strategy decision.

Our study is not devoid of limitations. Firstly, the present study is a retrospective study with potential selection bias. To limit the influence of bias, propensity score matching was conducted to balance the baseline. Secondly, the data was extracted from single center, and the sample size is moderate. The multicenter study with a large scale is further required. Next, although we excluded the patients with the presence of inflammation, other unknown conditions may exist which affect the neutrophil, lymphocyte, and platelet. Finally, there is no standard cut-off value of SII, we determined the cut-off value based on our data. More studies are necessary to identify optimal cut-off value.

\section{Conclusions}

In conclusion, preoperative SII is associated with adverse factors for RCC. Furthermore, higher preoperative SII is an independent predictor of poor OS and CSS in surgically treated patients with nonmetastatic RCC. While more prospective and large scale studies are warranted to validate our findings.

\section{Abbreviations}


RCC: Renal Cell Carcinoma; OS: Overall Survival; CSS: Cancer-specific Survival; HR: Hazard Ratio; Cl: Confidence Interval; SII: Systemic Immune-inflammation Index; ROC: Receiver Operating Characteristic

\section{Declarations}

Author Contributions: Conception and design: Xiang Li and Xu Hu; Collection and assembly of data: Xu $\mathrm{Hu}$, Yan-Xiang Shao, and Zhi-Qiang Yang; Data analysis and interpretation: Xiang Li, Xu Hu, Wei-Chao Dou and San-Chao Xiong; Manuscript writing: All authors; Final approval of manuscript: All authors

Availability of data and materials: The data used during the current study are available from the corresponding author on reasonable request.

Ethical approval and consent to participate: All procedures performed in studies involving human participants were according to the ethical standards of the ethics committee of Sichuan University West China Hospital. The ethics committee of Sichuan University West China Hospital approved this study, and informed consent was waived by the board.

Competing interests: The authors declare that there is no conflict of interest.

Funding: None.

Acknowledgments: None.

\section{References}

1. Dy GW, Gore JL, Forouzanfar MH, Naghavi M, Fitzmaurice C. Global Burden of Urologic Cancers, 1990-2013. European urology. 2017;71(3):437-46.

2. Bray F, Ferlay J, Soerjomataram I, Siegel RL, Torre LA, Jemal A. Global cancer statistics 2018 : GLOBOCAN estimates of incidence and mortality worldwide for 36 cancers in 185 countries. CA: a cancer journal for clinicians. 2018;68(6):394-424.

3. Ljungberg B, Albiges L, Abu-Ghanem Y, Bensalah K, Dabestani S, Fernandez-Pello S, et al. European Association of Urology Guidelines on Renal Cell Carcinoma: The 2019 Update. European urology. 2019;75(5):799-810.

4. Williamson TJ, Pearson JR, Ischia J, Bolton DM, Lawrentschuk N. Guideline of guidelines: follow-up after nephrectomy for renal cell carcinoma. BJU international. 2016;117(4):555-62.

5. Jamil ML, Keeley J, Sood A, Dalela D, Arora S, Peabody JO, et al. Long-term Risk of Recurrence in Surgically Treated Renal Cell Carcinoma: A Post Hoc Analysis of the Eastern Cooperative Oncology Group-American College of Radiology Imaging Network E2805 Trial Cohort. European urology. 2020;77(2):277-81.

6. Unverzagt S, Moldenhauer I, Nothacker M, RossmeissI D, Hadjinicolaou AV, Peinemann F, et al. Immunotherapy for metastatic renal cell carcinoma. The Cochrane database of systematic reviews. 
2017;5:Cd011673.

7. Meyer E, Pasquier D, Bernadou G, Calais G, Maroun P, Bossi A, et al. Stereotactic radiation therapy in the strategy of treatment of metastatic renal cell carcinoma: A study of the Getug group. European journal of cancer (Oxford, England : 1990). 2018;98:38-47.

8. Mantovani A, Allavena P, Sica A, Balkwill F. Cancer-related inflammation. Nature. 2008;454(7203):436-44.

9. Schreiber RD, Old LJ, Smyth MJ. Cancer immunoediting: integrating immunity's roles in cancer suppression and promotion. Science (New York, NY). 2011;331(6024):1565-70.

10. Coffelt SB, de Visser KE. Cancer: Inflammation lights the way to metastasis. Nature. 2014;507(7490):48-9.

11. Huszno J, Kolosza Z, Mrochem-Kwarciak J, Rutkowski T, Skladowski K. The Role of NeutrophilLymphocyte Ratio, Platelet-Lymphocyte Ratio, and Platelets in the Prognosis of Metastatic Renal Cell Carcinoma. Oncology. 2019;97(1):7-17.

12. Guo J, Fang J, Huang X, Liu Y, Yuan Y, Zhang X, et al. Prognostic role of neutrophil to lymphocyte ratio and platelet to lymphocyte ratio in prostate cancer: A meta-analysis of results from multivariate analysis. International journal of surgery (London, England). 2018;60:216-23.

13. Hu B, Yang XR, Xu Y, Sun YF, Sun C, Guo W, et al. Systemic immune-inflammation index predicts prognosis of patients after curative resection for hepatocellular carcinoma. Clinical cancer research : an official journal of the American Association for Cancer Research. 2014;20(23):6212-22.

14. Lolli C, Basso U, Derosa L, Scarpi E, Sava T, Santoni M, et al. Systemic immune-inflammation index predicts the clinical outcome in patients with metastatic renal cell cancer treated with sunitinib. Oncotarget. 2016;7(34):54564-71.

15. Wang K, Diao F, Ye Z, Zhang X, Zhai E, Ren H, et al. Prognostic value of systemic immuneinflammation index in patients with gastric cancer. Chinese journal of cancer. 2017;36(1):75.

16. Zhang W, Wang R, Ma W, Wu Y, Maskey N, Guo Y, et al. Systemic immune-inflammation index predicts prognosis of bladder cancer patients after radical cystectomy. Annals of translational medicine. 2019;7(18):431.

17. Taneja K, Williamson SR. Updates in Pathologic Staging and Histologic Grading of Renal Cell Carcinoma. Surgical pathology clinics. 2018;11(4):797-812.

18. Moch H, Cubilla AL, Humphrey PA, Reuter VE, Ulbright TM. The 2016 WHO Classification of Tumours of the Urinary System and Male Genital Organs-Part A: Renal, Penile, and Testicular Tumours. European urology. 2016;70(1):93-105.

19. Kurth T, Walker AM, Glynn RJ, Chan KA, Gaziano JM, Berger K, et al. Results of multivariable logistic regression, propensity matching, propensity adjustment, and propensity-based weighting under conditions of nonuniform effect. American journal of epidemiology. 2006;163(3):262-70.

20. Aziz MH, Sideras K, Aziz NA, Mauff K, Haen R, Roos D, et al. The Systemic-immune-inflammation Index Independently Predicts Survival and Recurrence in Resectable Pancreatic Cancer and its 
Prognostic Value Depends on Bilirubin Levels: A Retrospective Multicenter Cohort Study. Annals of surgery. 2019;270(1):139-46.

21. Chen JH, Zhai ET, Yuan YJ, Wu KM, Xu JB, Peng JJ, et al. Systemic immune-inflammation index for predicting prognosis of colorectal cancer. World journal of gastroenterology. 2017;23(34):6261-72.

22. Jan $\mathrm{HC}$, Yang $\mathrm{WH}, \mathrm{Ou} \mathrm{CH}$. Combination of the Preoperative Systemic Immune-Inflammation Index and Monocyte-Lymphocyte Ratio as a Novel Prognostic Factor in Patients with Upper-Tract Urothelial Carcinoma. Annals of Surgical Oncology. 2019;26(2):669-84.

23. Chrom P, Zolnierek J, Bodnar L, Stec R, Szczylik C. External validation of the systemic immuneinflammation index as a prognostic factor in metastatic renal cell carcinoma and its implementation within the international metastatic renal cell carcinoma database consortium model. International journal of clinical oncology. 2019;24(5):526-32.

24. De Giorgi U, Procopio G, Giannarelli D, Sabbatini R, Bearz A, Buti S, et al. Association of Systemic Inflammation Index and Body Mass Index with Survival in Patients with Renal Cell Cancer Treated with Nivolumab. Clinical cancer research : an official journal of the American Association for Cancer Research. 2019;25(13):3839-46.

25. Ozbek E, Besiroglu H, Ozer K, Horsanali MO, Gorgel SN. Systemic immune inflammation index is a promising non-invasive marker for the prognosis of the patients with localized renal cell carcinoma. International urology and nephrology. 2020.

26. Grivennikov SI, Greten FR, Karin M. Immunity, inflammation, and cancer. Cell. 2010;140(6):883-99.

27. Tan KW, Chong SZ, Wong FH, Evrard M, Tan SM, Keeble J, et al. Neutrophils contribute to inflammatory lymphangiogenesis by increasing VEGF-A bioavailability and secreting VEGF-D. Blood. 2013;122(22):3666-77.

28. Lopez-Lago MA, Posner S, Thodima VJ, Molina AM, Motzer RJ, Chaganti RS. Neutrophil chemokines secreted by tumor cells mount a lung antimetastatic response during renal cell carcinoma progression. Oncogene. 2013;32(14):1752-60.

29. Huang J, Dahl DM, Dong L, Liu Q, Cornejo K, Wang Q, et al. Preoperative Neutrophil-to-Lymphocyte Ratio and Neutrophilia Are Independent Predictors of Recurrence in Patients with Localized Papillary Renal Cell Carcinoma. BioMed research international. 2015;2015:891045.

30. Jensen HK, Donskov F, Marcussen N, Nordsmark M, Lundbeck F, von der Maase H. Presence of intratumoral neutrophils is an independent prognostic factor in localized renal cell carcinoma. Journal of clinical oncology : official journal of the American Society of Clinical Oncology. 2009;27(28):4709-17.

31. Donskov F, von der Maase H. Impact of immune parameters on long-term survival in metastatic renal cell carcinoma. Journal of clinical oncology : official journal of the American Society of Clinical Oncology. 2006;24(13):1997-2005.

32. Labelle M, Begum S, Hynes RO. Direct signaling between platelets and cancer cells induces an epithelial-mesenchymal-like transition and promotes metastasis. Cancer cell. 2011;20(5):576-90. 
33. Moschini M, Suardi N, Pellucchi F, Rocchini L, La Croce G, Capitanio U, et al. Impact of preoperative thrombocytosis on pathological outcomes and survival in patients treated with radical cystectomy for bladder carcinoma. Anticancer research. 2014;34(6):3225-30.

34. Yun ZY, Zhang X, Liu ZP, Liu T, Wang RT, Chen H. Association of decreased mean platelet volume with renal cell carcinoma. International journal of clinical oncology. 2017;22(6):1076-80.

35. Joseph N, Dovedi SJ, Thompson C, Lyons J, Kennedy J, Elliott T, et al. Pre-treatment lymphocytopaenia is an adverse prognostic biomarker in muscle-invasive and advanced bladder cancer. Annals of oncology : official journal of the European Society for Medical Oncology. 2016;27(2):294-9.

36. Saroha S, Uzzo RG, Plimack ER, Ruth K, Al-Saleem T. Lymphopenia is an independent predictor of inferior outcome in clear cell renal carcinoma. The Journal of urology. 2013;189(2):454-61.

37. Giraldo NA, Becht E, Vano Y, Petitprez F, Lacroix L, Validire P, et al. Tumor-Infiltrating and Peripheral Blood T-cell Immunophenotypes Predict Early Relapse in Localized Clear Cell Renal Cell Carcinoma. Clinical cancer research : an official journal of the American Association for Cancer Research. 2017;23(15):4416-28.

\section{Figures}

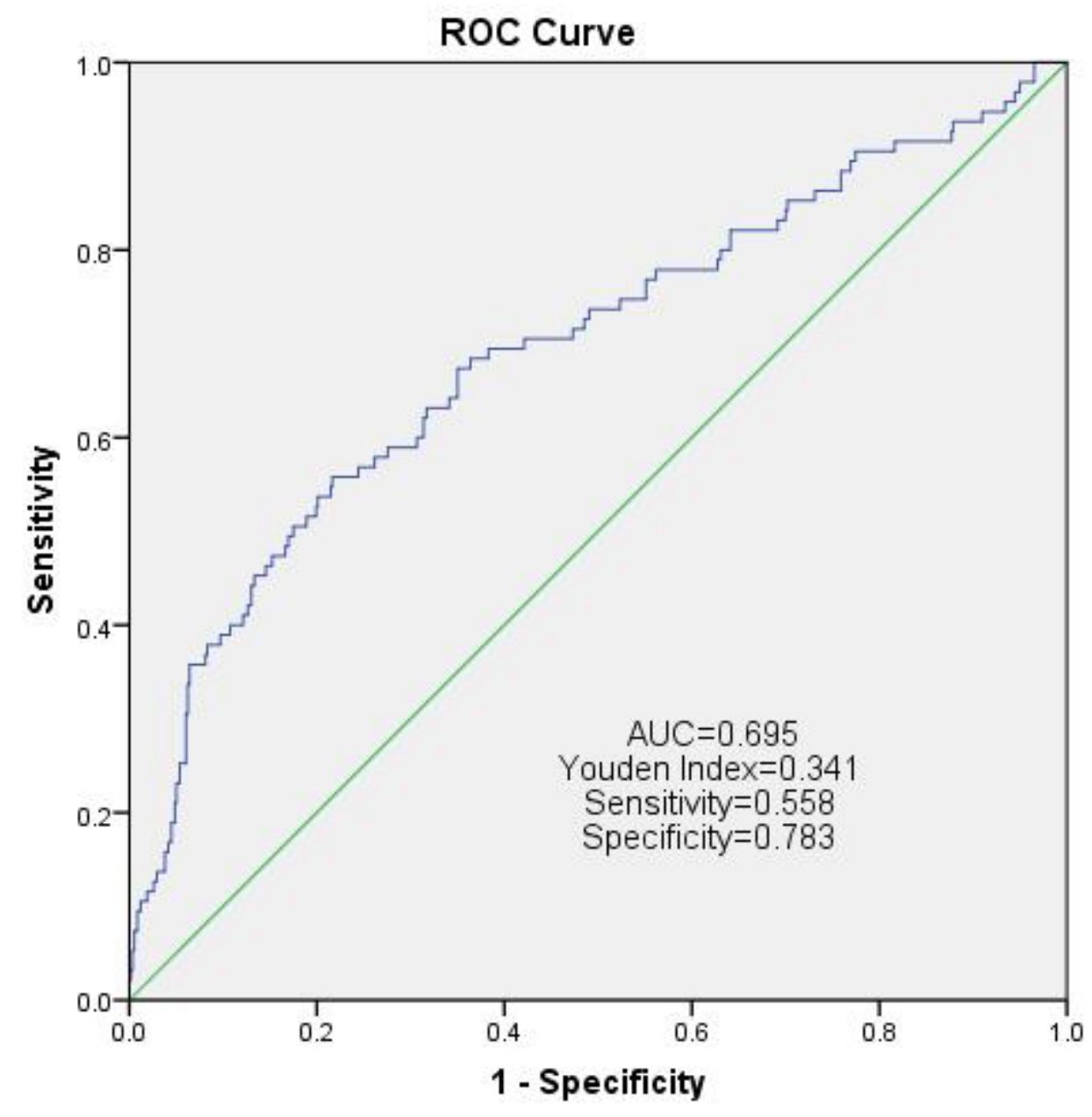


Figure 1

ROC curve analysis of CSS for RCC patients

SII $+<529+>529$

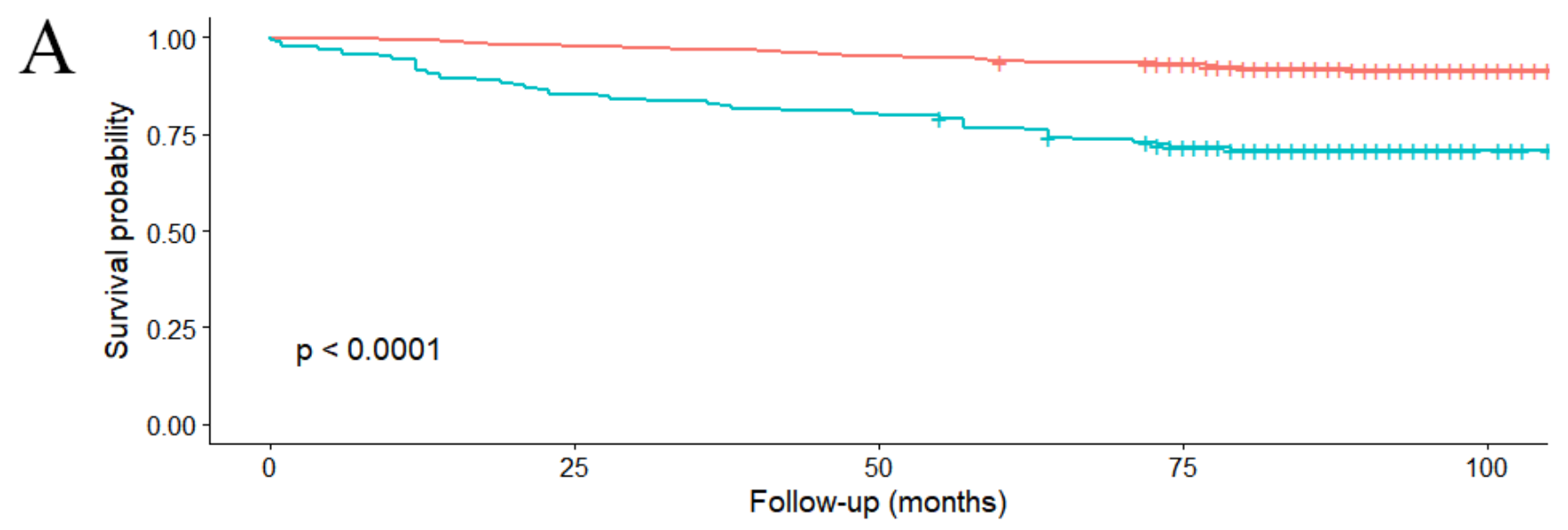

Number at risk

\begin{tabular}{c|ccccc}
$\overline{\bar{\omega}}>529-529$ & 483 & 472 & 460 & 399 & 64 \\
163 & 139 & 131 & 102 & 13 \\
\hline 0 & 25 & 50 & 75 & 100
\end{tabular}

SII $+<529+>529$

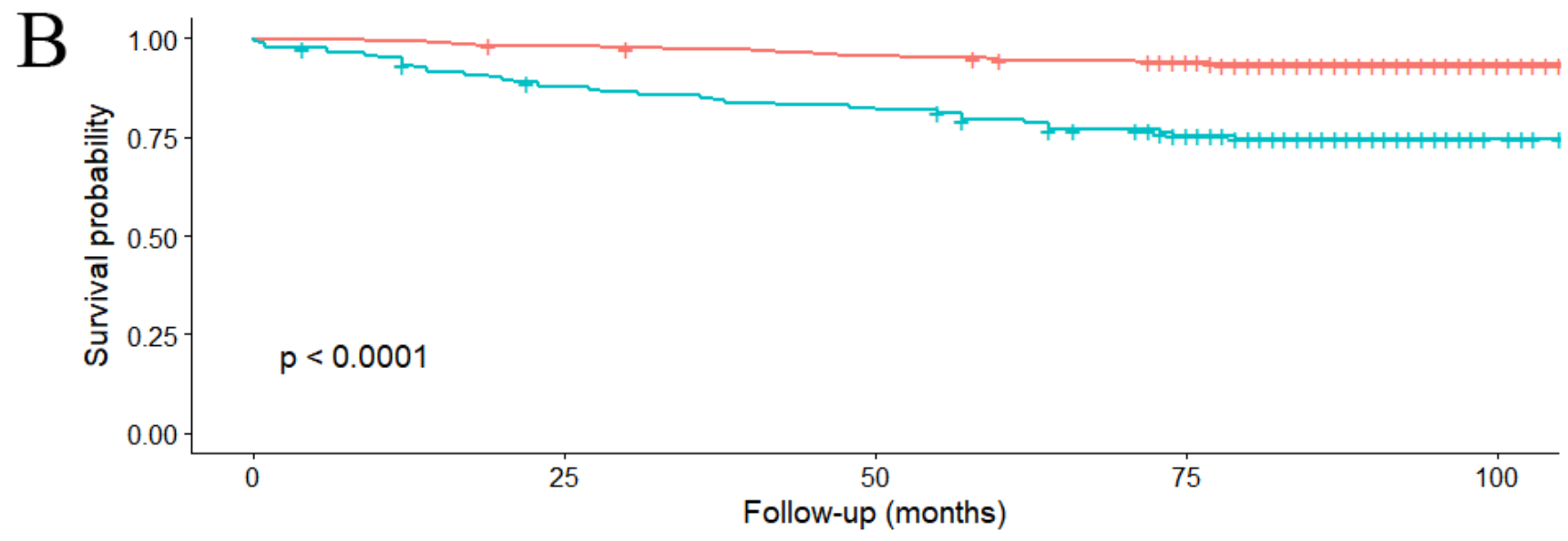

Number at risk

\begin{tabular}{|c|c|c|c|c|}
\hline 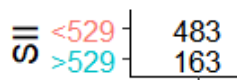 & $\begin{array}{l}472 \\
139 \\
\end{array}$ & $\begin{array}{l}460 \\
131\end{array}$ & $\begin{array}{l}399 \\
102 \\
\end{array}$ & $\begin{array}{l}64 \\
13 \\
\end{array}$ \\
\hline 0 & 25 & $\begin{array}{l}50 \\
u p(n\end{array}$ & 75 & 100 \\
\hline
\end{tabular}

Figure 2

Association between SII and A): OS and B): CSS in non-metastatic RCC patients after nephrectomy before PSM 
SII $+<529+>529$

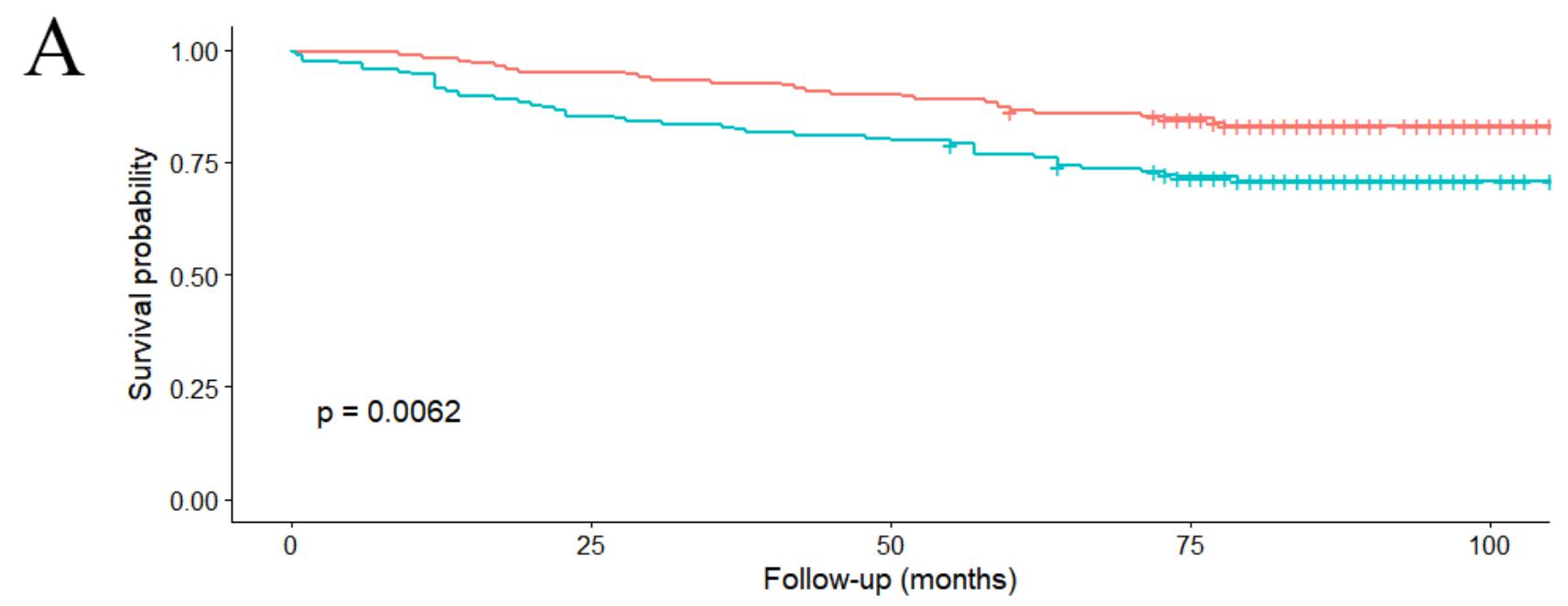

Number at risk

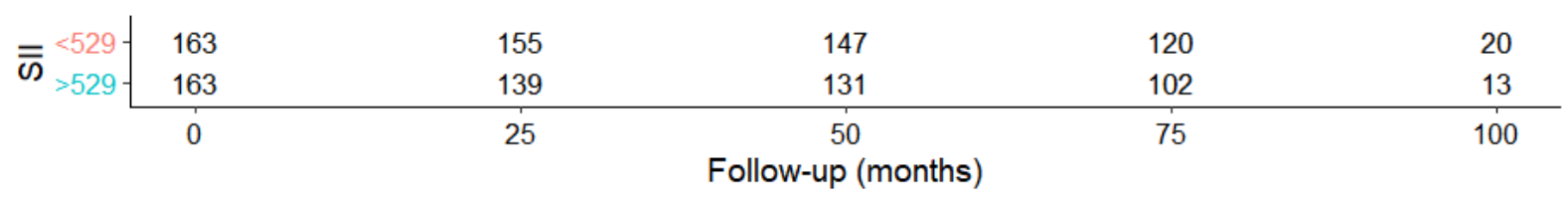

$\mathrm{SII}+<529+>529$

$\mathrm{B}$

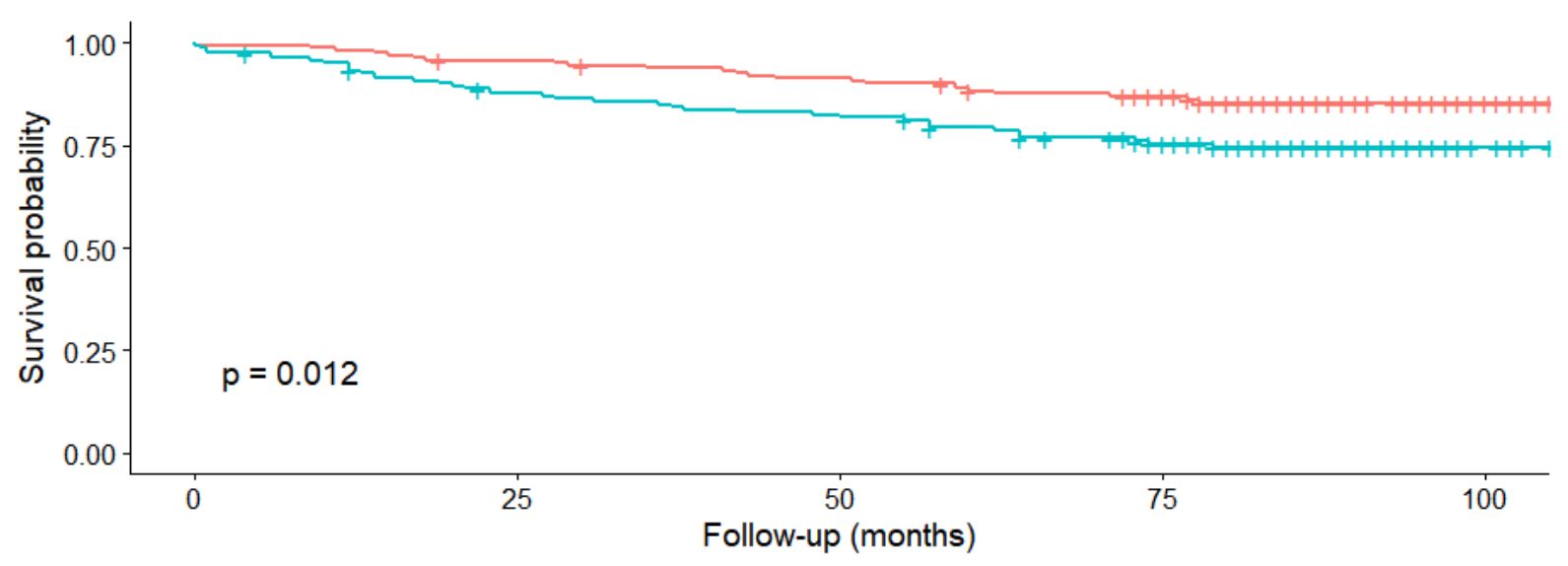

Number at risk

\begin{tabular}{c|ccccc}
$\overline{\boldsymbol{\omega}}<529-529$ & 163 & 155 & 147 & 120 & 20 \\
\hline 163 & 139 & 131 & 102 & 13 \\
\hline 0 & 25 & 50 & 75 &
\end{tabular}

\section{Figure 3}

Association between SII and A): OS and B): CSS in non-metastatic RCC patients after nephrectomy after PSM 